\title{
X-RAYING INJURY FINDINGS IN SOUTH AFRICA'S ANTI-DUMPING INVESTIGATIONS
}

\author{
GUSTAV BRINK *
}

\section{INTRODUCTION}

Internationally anti-dumping investigations are conducted under the rules of the World Trade Organization (WTO) Anti-Dumping Agreement (AD Agreement). ${ }^{1}$ Where a WTO member is not satisfied with the procedures used in an investigation by the importing country, it may refer the matter to the WTO Dispute Settlement Body, which will then appoint a panel to investigate whether the investigation was conducted in accordance with the provisions of the Agreement. The aggrieved member raises the specific issues it wants the panel to consider and specifies the relevant provisions of the relevant Agreement. ${ }^{2}$ Strictly speaking, these rulings only apply to the parties to the dispute and although stare decisis does not apply, these rulings provide insight into whether a future panel would uphold or strike down a member's procedures. South African anti-dumping procedures have been challenged in the WTO on four occasions, ${ }^{3}$ but to date no dispute involving South Africa has progressed to a panel.

In 2013 the panel in China-X-ray Equipment ${ }^{4}$ was requested to consider several issues, including China's injury and causality findings. These findings are scrutinised in this paper and used to determine to which extent South African procedures meet the requirements of the Agreement. The paper first sets out

* BCom, LLB LLD (University of Pretoria); gustav.brink@ gmail.com; Extraordinary Lecturer in Mercantile Law, University of Pretoria; Associate Director: XA International Trade Advisors, Pretoria. The author wishes to thank Ashley Nyaude, at the Department of Mercantile Law, University of Pretoria, for her research assistance.

1 Agreement on Implementation of Article VI of the General Agreement on Tariffs and Trade 1994, in WTO, The Results of the Uruguay Round of Multilateral Trade Negotiations, WTO (1995), pp.166-96.

2 See, e.g. South Africa-Anti-Dumping Duties on Frozen Meat of Fowls from Brazil WT/DS439/1 (25 June 2012).

3 See South Africa-Anti-Dumping Duties on Certain Pharmaceutical Products from India WT/DS168/1 (13 April 1999); South Africa-Definitive Anti-Dumping Measures on Blanketing from Turkey WT/DS288/1 (15 April 2003); South Africa-Anti-Dumping Measures on Uncoated Wood free Paper WT/DS374/1 (16 May 2008); South Africa-Meat of Fowls.

4 China-Definitive Anti-Dumping Duties on X-ray Security Inspection Equipment from the European Union WT/DS425/R (circulated 26 February 2013) (China-X-ray Equipment). 
the injury and causality requirements of the AD Agreement, followed by the like provisions in South Africa's legislation and highlighting any differences. It then analyses the findings in China-X-ray Equipment, before evaluating South Africa's procedures. It concludes with recommendations on how the South African procedures could be improved.

\section{INJURY AND CAUSALITY UNDER THE AD AGREEMENT}

The General Agreement on Tariffs and Trade (GATT) 1994 provides:

No contracting party shall levy any anti-dumping ... duty on the importation of any product of the territory of another contracting party unless it determines that the effect of the dumping ... is such as to cause or threaten material injury to an established domestic industry, or is such as to retard materially the establishment of a domestic industry. ${ }^{5}$

Although 'dumping' is clearly defined both in article VI of GATT ${ }^{6}$ and in the AD Agreement, ' 'material injury' is not defined in either document. As regards material injury, the $\mathrm{AD}$ Agreement provides that a 'determination of injury ... shall be based on positive evidence and involve an objective examination of both (a) the volume of the dumped imports and the effect of the dumped imports on prices in the domestic market for like products, and $(b)$ the consequent impact of these imports on domestic producers of such products' ${ }^{8}$ This provision thus sets out two separate examinations that need to be undertaken: first, in respect of the volume of dumped imports and the effect thereof on price, and, secondly, the consequent impact of these imports on the domestic industry. In article 3(2), the AD Agreement then provides as follows:

With regard to the volume of the dumped imports, the investigating authorities shall consider whether there has been a significant increase in dumped imports, either in absolute terms or relative to production or consumption in the importing Member. With regard to the effect of the dumped imports on prices, the investigating authorities shall consider whether there has been a significant price undercutting by the dumped imports as compared with the price of a like product of the importing Member, or whether the effect of such imports is otherwise to depress prices to a significant degree or prevent price increases, which otherwise would have occurred, to a significant degree.

Like article 3(1), article 3(2) contains two elements. The first requires that it be determined whether there has been 'a significant increase' in the volume

5 Article VI(6)(a).

6 Article VI(1) of GATT.

7 Article 2(1) of the AD Agreement.

8 Ibid., article 3(1). 
of the dumped imports, either in absolute terms or relative to production or consumption in the importing member. No definition is provided as to the meaning of 'significant' either as regards this article or any of the following articles that use the same terminology. The second requirement is that an examination of prices needs to be undertaken. It must be determined whether there has been significant price undercutting by the dumped product, whether the domestic industry's prices have been significantly depressed, or whether the industry's prices have been significantly suppressed, that is, that necessary price increases could not be effected. Price injury is therefore a separate injury requirement and if 'significant' price injury cannot be found, whether expressed as price undercutting, depression or suppression, this requirement of the AD Agreement has not been met.

Article 3.4 of the AD Agreement, provides as follows:

The examination of the impact of the dumped imports on the domestic industry concerned shall include an evaluation of all relevant economic factors and indices having a bearing on the state of the industry, including actual and potential decline in sales, profits, output, market share, productivity, return on investments, or utilization of capacity; factors affecting domestic prices; the magnitude of the margin of dumping; actual and potential negative effects on cash flow, inventories, employment, wages, growth, ability to raise capital or investments. This list is not exhaustive, nor can one or several of these factors necessarily give decisive guidance.

Panels and the Appellate Body have held that the determination of injury 'shall include an evaluation of all relevant economic factors and indices'. 9 Thus, each of the factors has to be evaluated. ${ }^{10}$ Every single indicator does not have to indicate a negative pattern and a holistic determination must be made on the overall evaluation of the factors. ${ }^{11}$ Article 3(6) then provides that:

The effect of the dumped imports shall be assessed in relation to the domestic production of the like product when available data permit the separate identification of that production on the basis of such criteria as the production process, producers' sales and profits. If such separate identification of that production is not possible, the effects of the dumped imports shall be assessed by the examination

9 Article 3(4) of the AD Agreement, as interpreted by WTO EC-Bed Linen Panel Report, para. 6.167; WTO Guatemala-Cement II Panel Report, para. 8.283; WTO Mexico-HFCS Panel Report para. 7.128; WTO Thailand-H-Beams Panel Report, para. 7.231; WTO Egypt-Rebar Panel Report, para. 7.37 .

10 See, e.g. Mexico-HFCS, para. 7.129, where it was held that: while the authorities may determine that some factors are not relevant to or do not weigh significantly in the decision, the authorities may not simply disregard such factors, but must explain their conclusion as to the lack of relevance or significance of such factors' and that 'authorities are required to consider, and their determination must reflect the consideration of, all the factors concerning injury.

11 Ibid., Mexico-HFCS, para. 7.129. 
of the production of the narrowest group or range of products, which includes the like product, for which the necessary information can be provided.

This shows the importance of accurately determining the product to be investigated, as well as the domestic like product. If the scope of the investigation is too wide, it may be difficult to prove injury, but if the scope is too narrow, it may be very easy to circumvent any measures imposed. At the same time, in many industries different products may be produced on the same equipment, making it difficult to determine injury strictly on the basis of the domestic like product only.

Although article 3(4) specifically relates to injury and article 3(5) to causality, there is some overlap between the two articles. Thus, it is submitted that the 'margin of dumping' is not an injury factor, but can merely be an indication of the cause of injury. Likewise, 'factors affecting domestic prices' cannot be an injury indicator, but are related to the causality determination. These therefore also have to be taken into consideration in the determination of causality. As regards causality, the final issue considered in this article, the AD Agreement provides as follows:

It must be demonstrated that the dumped imports are, through the effects of dumping ... causing injury within the meaning of this Agreement. The demonstration of a causal relationship between the dumped imports and the injury to the domestic industry shall be based on an examination of all relevant evidence before the authorities. The authorities shall also examine any known factors other than the dumped imports which at the same time are injuring the domestic industry, and the injuries caused by these other factors must not be attributed to the dumped imports... ${ }^{12}$

Evident from this provision is not only that an investigating authority must determine whether there is a link between the dumped imports and the domestic industry's material injury but also that it must undertake an analysis to determine whether there are other factors contributing to the industry's woes and that the effects of these other factors must be eliminated. An anti-dumping measure may only be imposed if a finding is made that dumping caused injury to the domestic industry. This, then, sets out the legal position under the AD Agreement. The next section considers the legal position pertaining to injury determinations in South Africa.

\section{INJURY AND CAUSALITY UNDER SOUTH AFRICAN LEGISLATION}

South Africa's primary legislation related to trade remedies is the ITA Act, ${ }^{13}$ but it does not contain any reference to injury and these provisions are found in the

12 Article 3(5) of the AD Agreement.

13 International Trade Administration Act 71 of 2002. 
Anti-Dumping Regulations (the ADR). ${ }^{14}$ Injury and causality provisions are contained in regulations $13-17$, while certain injury-specific terminology is defined in ADR 1.

The ADR define: ${ }^{15}$

- 'price disadvantage' as the extent to which the price of the imported product is lower than the unsuppressed selling price of the Southern African Customs Union (SACU) like product;

- 'price depression' as taking place where the SACU industry's exfactory selling price decreases during the investigation period;

- 'price suppression' as taking place where the cost-to-price-ratio of the industry increases, or where the industry sells at a loss during the investigation period or part thereof; and

- 'price undercutting' as the extent to which the price of the imported product is lower than the price of the SACU like product, measured at the appropriate point of comparison.

There is no like provision to 'price disadvantage' in the AD Agreement. This, however, is only used in the determination of the lesser duty rule, that is, where the International Trade Administration Commission (ITAC) determines whether a duty lower than the full margin of dumping would suffice to remove injury caused by the dumping. ${ }^{16}$ Although the other three terms are used in the Agreement, they are not defined there. In this regard, the ADR are more detailed than the Agreement. This notwithstanding, the notion of price suppression differs between the Agreement and the Regulations. Price suppression under the Agreement is understood to take place when the dumped imports 'prevent price increases, which otherwise would have occurred', whereas under the Regulations it does not matter whether the price increased or decreased, but whether the cost-to-price ratio changed negatively or the industry is selling at a loss. ${ }^{17}$

The ADR provide that in determining causality, ITAC shall 'consider' all relevant factors, including the change in the volume of dumped imports, whether absolute or relative to the production or consumption in the SACU market. ${ }^{18}$ There is no reference to the AD Agreement requirement that such increase has to be 'significant'. As regards prices, the ADR provide that in determining causality, ITAC shall consider 'the price undercutting experienced by the SACU industry vis-à-vis the imported products'. ${ }^{19}$ No reference is made to the AD Agreement requirement that such undercutting be 'significant'.

14 See N3197 in Government Gazette 25684, 13 November 2003.

15 ADR 1.

16 ADR 17.

17 Note that in China-X-ray Equipment para. 7.20, the EU argues 'MOFCOM found that the dumped imports forced [the Chinese producer] to lower its prices by more than the reduction in its unit cost of production' and that this is indicative of price depression rather than price suppression. In South Africa this would have been found indicative of both price depression and price suppression.

18 ADR 16(1)(a)

19 ADR 16(1)(b) 
The second sub-regulation on injury lists the factors to be considered to determine injury. It requires ITAC to consider whether there 'have been significant changes' in the 'domestic performance' of the SACU industry as regards sales volume; profit and loss; output; market share; productivity; return on investments; capacity utilisation; cash flow; inventories; employment; wages; growth; ability to raise capital or investments; and any other relevant factors placed before the Commission. The AD Agreement provision requires an analysis of those factors 'having a bearing on the state of the industry', ${ }^{20}$ without limiting it to the 'domestic performance' of the industry. Direct comparison of the regulation and the AD Agreement provision shows that some factors are missing from the list in the ADR. These are 'factors affecting domestic prices' and 'the magnitude of the margin of dumping', both of which are included in the regulation dealing with causality. Other differences include that the AD Agreement requires an 'evaluation' of each of these factors, whereas the ADR only require ITAC to 'consider' the factors, while the AD Agreement also requires an authority to evaluate both the 'actual and potential decline' in and the 'actual and potential negative effects' on the different injury factors, whereas the ADR contain no reference to the potential declines and effects. Finally, whereas the AD Agreement requires an authority to evaluate the actual and potential decline in 'sales', the Regulations only require ITAC to consider sales 'volume', which indicates that the Regulations do not require a consideration of sales values. It is not clear why these differences exist. ${ }^{21}$

In line with the requirement of the AD Agreement, the ADR require ITAC to consider each of the listed factors 'for the product under investigation only or, where such analysis is not possible, for the narrowest group of products for which such analysis can be made'. ${ }^{22}$ Although technically the wording is wrong, as the product under investigation is the dumped product, it is clear that the intention is that only the domestic like product is to be considered and not other products produced by the industry.

As regards causality, the ADR provide that ITAC must determine whether there is a causal link between the dumping and the injury. ${ }^{23}$ It requires ITAC to consider at least the following factors in determining causality:

- the change in the volume of dumped imports, whether absolute or relative to production or consumption in SACU;

- the price undercutting experienced by the industry vis-à-vis the imported products;

- the market share of the dumped imports;

20 Article 3(4) of the AD Agreement.

21 See Brink (2004), 'A Theoretical Framework for Anti-dumping Law in South Africa' (LLD thesis, University of Pretoria) pp. 714, 716, 756, 757, 760, 765, 768, 786-787, 790, 791, 807, $829,835,837,841,856,868,886,891,892,900,903,905,908-9,926,930-1$ and 933 for examples of inconsistencies between the ADR and the AD Agreement.

22 ADR 13(4)

23 ADR 16(4). 
- the magnitude of the margin of dumping; and

- the price of undumped imports available in the market. ${ }^{24}$

This regulation corresponds roughly to the first part of article 3(5) of the AD Agreement. Note that the Regulations do not contain the word 'significant' as required by the AD Agreement. Finally, the ADR require that ITAC consider factors other than dumping that have contributed to the industry's injury and then lists the following factors 'that may be relevant in this respect' as:

- the volume and prices of imports not sold at dumped prices;

- contraction in demand or changes in the patterns of consumption;

- trade restrictive trade practices of and competition between the foreign and SACU producers;

- developments in technology;

- other factors affecting SACU prices;

- 6. the industry's export performance; and

- 7. the productivity of the SACU industry. ${ }^{25}$

It also provides, in the same regulation, that any injury caused by such other factors may not be attributed to the dumping. The requirement to conduct a nonattribution analysis is limited by the provision that ITAC only has to consider such other factors to the extent 'that an interested party has submitted, or the Commission otherwise has, information on such factor' ${ }^{26}$

Having established the legal position both under the AD Agreement and South Africa's legislation, and having pointed out the differences, the next section considers the dispute settlement body's interpretation of the AD Agreement provisions in China-X-ray Equipment.

\section{THE PANEL'S INJURY AND CAUSALITY FINDINGS IN CHINA - X-RAY EQUIPMENT}

\section{A. Introduction}

In China-X-ray Equipment the European Union (EU) requested the panel to consider various perceived violations of the AD Agreement including, among others, material injury and causality. The panel dealt with these complaints under three separate sub-headings, the first relating to articles 3(1) and 3(2) of the Agreement, that is, the determination of price injury; the second with articles 3(1) and 3(4), that is, the determination of material injury; and the third with article $3(5)$, which relates to causality.

24 ADR 16(1)

25 ADR 16(5).

26 Ibid., ADR 16(5). Note that although no such limitation formally exists in the AD Agreement, the panel in China-X-ray Equipment, para. 7.267 indicated that where a party has alluded to factors affecting causality but has not supplied substantiating information, the authority is not required to consider such factors. See also EC-Tube or Pipe Fittings Appellate Body Report, para. 175. 


\section{B. Price undercutting}

The first question addressed by the panel regarding price undercutting was whether a proper comparison had been made between the dumped product price and the domestic like product price. This issue had already been addressed both by panels ${ }^{27}$ and the Appellate Body, ${ }^{28}$ although the panel in China-X-ray Equipment considered the issue in more detail. In the first case, EC-Tube or Pipe Fittings, the panel held that: 'the focus in a price undercutting analysis may be on differences between the imported and domestic like product that have a perceived importance to consumers'. ${ }^{29}$

This showed that differences between the dumped and domestic like product had to be taken into consideration in the price undercutting determination. In EC-Fasteners the panel noted that 'adjustments in the context of price undercutting analysis may be a useful means of ensuring that the requirements of objective examination of positive evidence in Article 3.1 are satisfied, as might the use of carefully defined product categories for the collection of price information' ${ }^{30}$ Finally, in China-GOES the Panel indicated that dumped product and domestic like product prices had to be 'properly comparable', ${ }^{31}$ while the Appellate Body held that 'an investigating authority must ensure comparability between prices that are being compared'. ${ }^{32}$ It further noted that a determination of injury had to involve an 'objective examination' of the effect of subject imports on the prices of domestic like products, which could not take place 'if subject import and domestic prices were not comparable'. ${ }^{33}$ It concluded that the lack of comparability of products would also affect the analysis of price depression and price suppression, thereby confirming that not only was there a requirement that prices of the dumped and domestic like products had to be properly comparable but also that prices had to be comparable for the domestic like product inter se, that is, an average price cannot be determined for a group of products where such products are not homogeneous, but that prices have to be compared on a modelby-model basis to determine whether there had indeed been price depression and suppression. ${ }^{34}$

The X-ray equipment investigation in China related to two clear product categories: 'low-energy' and 'high-energy' scanners. Low-energy scanners were

27 China-Countervailing and Anti-Dumping Duties on Grain Oriented Flat-Rolled Electrical Steel from the United States WT/DS414/R (15 June 2012) (China-GOES Panel Report); European Communities-Anti-Dumping Duties On Malleable Cast Iron Tube Or Pipe Fittings From Brazil WT/DS219/R (7 March 2003) (EC-Tube Or Pipe Fittings Panel Report); and European Communities-Definitive Anti-Dumping Measures On Certain Iron Or Steel Fasteners From China WT/DS397/R (3 December 2010) (EC-Fasteners Panel Report).

28 China-Countervailing and Anti-Dumping Duties on Grain Oriented Flat-Rolled Electrical Steel from the United States WT/DS414/AB/R (18 October 2012) (China-GOES Appellate Body Report).

29 EC - Tube or Pipe Fittings Panel Report paras 7.292-7.293; author's emphasis).

30 EC-Fasteners Panel Report, para. 7.328.

31 China-GOES Panel Report, para. 7.530.

32 China-GOES Appellate Body Report, para. 200.

33 Ibid., 200.

34 Ibid., 200. 
typically used for scanning hand luggage at airports and high-energy scanners for scanning rail carriages, trucks or marine cargo containers. Accordingly, there were significant differences between the two categories not only in the amount of energy they consumed but also in size. At least 20 different types of lowenergy scanners were imported from the EU and at least four different low-energy scanners were offered for sale by the domestic industry. No high-energy scanners were imported from the EU, but the Chinese domestic industry, consisting of a single company (Nuctech), sold various high-energy scanners. In its determination of price depression, China compared the average price of all scanners sold by the Chinese domestic industry at the beginning of the investigation period with the average price of all scanners sold by the industry at the end of the period, without making any allowance for differences between the various models or for a change in the product mix over time. ${ }^{35}$ Likewise, in determining price undercutting, China's Ministry of Commerce (MOFCOM) compared the average price for all (low-energy) scanners imported from the EU to the average selling price of all (low- and high-energy) scanners sold by the Chinese domestic industry. ${ }^{36}$

During its analysis of the facts, the panel specifically found that although in principle the domestic products were like products to the dumped products, this did not indicate that the different models and prices could be directly compared. ${ }^{37}$ It further found that as MOFCOM had not requested model-by-model or transaction-by-transaction pricing data from industry, it was clear that it had not considered making the comparison at this level ${ }^{38}$ despite that fact that 'it is necessary to ensure that the prices being considered are actually comparable'. ${ }^{39}$

It finally held that if two products are compared at different levels of trade, without adjustment, the outcome of this comparison would not lead to an objective, unbiased analysis' ${ }^{40}$ Thus, any investigating authority making a determination of price undercutting has to properly ensure a fair comparison between the dumped product price and the domestic like product price, and that any determination of price suppression or depression also has to take into consideration differences between the different models sold by the domestic industry.

\section{Product-specific injury finding}

Many investigations deal with products where there is not a perfect overlap between the dumped product and the domestic like product or with cases where injury cannot be determined in respect of the domestic like product on its own,

35 China-X-ray Equipment Panel Report, para. 7.57.

36 Ibid., paras 7.68-7.92.

37 Ibid., para. 7.65.

38 Ibid., para. 7.59. The panel noted that China could not rely on the fact that the exporter had not submitted information on this basis as rationale for its methodology, as it would not have been in a position to use the exporter's information in the absence of similar information from the domestic industry.

39 Ibid., para. 7.49

40 Ibid., para. 7.50 . 
but only in respect of a wider product range. This may be true of products such as welded stainless steel tubes and pipes, which may be produced on the same machinery as galvanised tubes and pipes, or seamless tubes and pipe, and where separate information on capacity, employment, wages and investments may not be available. The same happens where the imported product is either of a narrower or wider range than the domestic like product, for instance, where imported screws cover a wider, or narrower, range of sizes than the domestic like product.

In US-Hot-rolled Steel the Appellate Body found that 'the injury examination must focus on the totality of the "domestic industry" and not simply on one party, sector or segment of it', ${ }^{41}$ and noted that 'it may be "highly pertinent", from an economic perspective, for an investigating authority to undertake an evaluation of particular parts, sectors or segments within a domestic industry in assessing the state of the industry as a whole', ${ }^{42}$ although such analysis must still be made in an 'objective manner'. While the Appellate Body has commented that 'supplementing an assessment of the state of the entire domestic industry with a segmented analysis may be highly pertinent in some circumstances' it has never considered whether a failure to conduct an analysis by sector may be inconsistent with articles 3(1) and 3(4)of the AD Agreement.

In China-X-ray Equipment, in considering product differences between the domestic like product and the imported product, the question was whether the injury analysis should have focused on the low-energy scanner industry only or on the total X-ray scanner industry. The panel did not complete the analysis, but it is submitted that the imports could not have caused injury to the industry producing high-energy scanners, as these are not interchangeable, and these scanners should therefore have been excluded both from the determination of material injury and of like product. The problem therefore lies as much with the injury determination as with the domestic like product determination, if not more with the latter. Accordingly, it may have further strengthened the EU's case if it had argued that the like product was determined incorrectly.

\section{Material injury: the $\mathbf{1 5}$ factors}

The Appellate Body ${ }^{43}$ and several panels ${ }^{44}$ have already held that all 15 injury factors listed under article 3(4) of the AD Agreement have to be taken into

41 Ibid., para. 7(187), with reference to US-Hot Rolled Steel Appellate Body Report, para. 190.

42 Ibid., with reference to US-Hot Rolled Steel Appellate Body Report, para. 195.

43 In Thailand-H-Beams, para. 125 the Appellate Body stated:

[t]he Panel concluded its comprehensive analysis by stating that 'each of the fifteen individual factors listed in the mandatory list of factors in Article 3.4 must be evaluated by the investigating authorities...'?

We agree with the Panel's analysis in its entirety, and with the Panel's interpretation of the mandatory nature of the factors mentioned in article 3.4 of the AD Agreement.

44 See, e.g. WTO EC-Bed Linen Panel Report, para. 6(167); WTO Guatemala-Cement II Panel Report, paragraph 8(283); WTO Mexico-HFCS Panel Report, para. 7(128); WTO ThailandH-Beams Panel Report, para. 7(231); WTO Egypt-Rebar Panel Report, para. 7(36); WTO Argentina-Poultry Panel Report, paragraph 7(314); WTO EC-Tube or Pipe Fittings Panel Report, para. 7(304). 
consideration in the determination of material injury, even though this does not necessarily means that there had to be 15 separate findings, ${ }^{45}$ and the panel in China $X$-ray Equipment concurred with this view. ${ }^{46}$ In addition, panels have held that each of these factors have to be 'evaluated' ${ }^{47}$ that 'the mere recital of data does not constitute explanation, or findings and conclusions, sufficient to satisfy the requirements' ${ }^{48}$ of the $\mathrm{AD}$ Agreement and that 'an evaluation of a factor ... is not limited to a mere characterisation of its relevance or irrelevance' but 'implies the analysis of data through placing it in context in terms of the particular evolution of the data pertaining to each factor individually, as well as in relation to other factors examined' ${ }^{49}$ In EC-Bed Linen (Article 21.5-India) the panel held that:

an 'evaluation' is a process of analysis and assessment requiring the exercise of judgment on the part of the investigating authority. It is not simply a matter of form, and the list of relevant factors to be evaluated is not a mere checklist. As the relative weight or significance of a given factor may naturally vary from investigation to investigation, the investigating authority must therefore assess the role, relevance and relative weight of each factor in the particular investigation. Where the authority determines that certain factors are not relevant or do not weigh significantly in the determination, the authority may not simply disregard such factors, but must explain their conclusion as to the lack of relevance or significance of such factors. The assessment of the relevance or materiality of certain factors, including those factors that are judged to be not central to the decision, must therefore be at least implicitly apparent from the determination. Silence on the relevance or irrelevance of a given factor will not suffice..$^{50}$

In considering the information before it in X-ray Equipment, the panel considered the EU's complaint that China had not properly evaluated the information before it, as the information it relied on differed in critical respects from the information submitted by the only Chinese producer. MOFOM indicated that Nuctech's information was adjusted following verification thereof and that it had indeed relied on the correct information. The panel agreed with MOFCOM and indicated that authorities had an obligation to make a determination based on positive evidence. ${ }^{51}$

45 EC-Tube or Pipe Fittings Appellate Body Report, para. 161.

46 China-X-ray Equipment Panel Report, para. 7(181).

47 WTO, Mexico-HFCS Panel Report, para. 7(140), note 610.

48 Ibid.

49 WTO, EC-Tube or Pipe Fittings Panel Report, para. 7(314) (footnotes omitted). See also WTO, Thailand H-Beams panel Report, para. 7(161); WTO Egypt-Rebar Panel Report, para. 7(44); WTO, Argentina-Preserved Peaches Panel Report, para. 7(97); WTO, U.S. - HotRolled Steel Appellate Body Report, para. 197; WTO, U.S. - Hot-Rolled Steel Panel Report, para.7.232-7.233.

50 Panel Report, EC-Bed Linen (Article 21.5-India), para. 6(162).

51 China-X-ray Equipment Panel Report, para. 7(101). Note that the question whether MOFCOM should have made the updated information available to parties could not be addressed under 
Although China had evaluated all 14 the other factors, the panel held that MOFCOM had not 'evaluated' the margin of dumping as an injury factor but merely listed the margins of dumping both for the cooperating exporter and for all other exporters. ${ }^{52}$ The panel stated that 'the simple listing of the margins ... is not sufficient evidence that the magnitude of the margin of dumping was evaluated in the context of examining the state of the domestic industry' and that 'an investigating authority is required to evaluate the magnitude of the margin of dumping and to assess its relevance and the weight to be attributed to it in the injury assessment' ${ }^{53}$ It therefore rejected China's argument that the fact that it had imposed anti-dumping measures indicates that it concluded that the dumping margins were not de minimis as this would render its inclusion in the list in article 3(4) superfluous. ${ }^{54}$ This confirms that a 'mere listing' is insufficient and that each injury factor has to be comprehensively evaluated and that such evaluation has to be published.

\section{E. Interaction between injury factors}

The EU argued that MOFCOM failed to make a proper evaluation of the overall development and interaction among injury factors. ${ }^{55}$ It contested two different aspects of MOFCOM's examination of the injury factors and claimed that each of these aspects individually gave rise to a violation of articles 3(1) and 3(4). ${ }^{56}$ First, it argued that MOFCOM did not conduct an objective examination when considering the interaction between positive and negative injury factors and that MOFCOM had failed to examine all factors in their proper context and, secondly, that MOFCOM had failed to take into account all facts and arguments on the record relating to the state of the industry. The parties agreed that MOFCOM had found only seven of the sixteen factors to be indicative of material injury and the EU complained that MOFCOM had failed to indicate 'why the negative developments in the industry were such as to outweigh the positive developments' ${ }^{57}$

In support of its arguments the EU argued that MOFCOM found certain factors to be indicative of injury 'by ignoring positive trends exhibited by each of the factors at issue, making contradictory observations and failing to explain the basis for its assertions regarding certain injury indicia'. ${ }^{58}$ In this regard, it relied on Thailand $H$-Beams, where the panel held that:

articles 3(1) and 3(4), as it relates to information that should be made available under article 6(5).

52 Ibid., para. 7(182).

53 Ibid., para. 7(183).

54 Ibid., para. 7(184).

55 Ibid., para. 7(190).

56 Ibid., para. 7(191).

57 Ibid., para. 7(214).

58 Ibid., para. 7(193). 
While we do not consider that such positive trends in a number of factors during the [POI] would necessarily preclude the investigating authorities from making an affirmative determination of injury, we are of the view that such positive movements in a number of factors would require a compelling explanation of why and how, in light of such apparent positive trends, the domestic industry was, or remained, injured within the meaning of the Agreement. In particular, we consider that such a situation would require a thorough and persuasive explanation as to whether and how such positive movements were outweighed by any other factors and indices which might be moving in a negative direction during the [investigation period]. ${ }^{59}$

In this regard, MOFCOM found that the industry experienced losses throughout the period of investigation, albeit decreasing losses over the period. MOFOM, however, failed to indicate in its final report on what basis it had concluded that the domestic industry did not realise the 'expected profits', which was an important element of its reasoning. The Panel rejected MOFCOM's arguments that there was no need to calculate or quantify the amount of such 'expected profits' as 'an objective and even-handed examination of the expected level of profit, by which the industry's actual profit level was assessed, needs to be based on more than an assertion that the 'company expected to be profitable'. ${ }^{60}$ The Panel indicated that '[s]ome form of estimation, calculation or explanation regarding why profitability in the absence of subject imports was a reasonable expectation should have been provided' ${ }^{61}$ The Panel further indicated that in its view:

an even-handed examination of profits required an acknowledgement of the positive trend in which this factor was moving and an accompanying explanation regarding why, in the light of this and other positive factors, the industry should nevertheless be considered injured. In the Panel's view, focusing only on absolute levels, and ignoring trends, has the potential to give a partial picture of the state of an industry. ${ }^{62}$

As regards cash flow, the Panel held that although there was negative cash flow in each of the three years of the investigation period, and although this could be indicative of injury, 'an objective and impartial examination would have required an acknowledgement and analysis of the fluctuations in the factors over the [investigation period], including the upward trend ... experienced in the final year'. ${ }^{63}$ Similarly, with respect to employment, the Panel found that although an

59 Thailand-H-Beams Panel Report, para. 7(249). See also EC-Countervailing Measures on DRAM Chips Panel Report, para. 7(372) and EC-Fasteners Panel Report, para. 7(399).

60 China-X-ray Equipment Panel Report, para. 7(200).

61 Ibid., para. 7(200).

62 Ibid., para. 7(201)

63 Ibid., para. 7(204). 
end-to-end comparison indicated a decline in employment, MOFCOM had failed to analyse the fluctuations within the investigation period and that this was "not consistent with an unbiased examination' ${ }^{64}$ The panel therefore found that:

aside from listing all 16 injury factors and the trends observed in them over the course of the POI, MOFCOM did not otherwise refer to or explain the developments. ... In the Panel's view, a more balanced approach would have been explicitly to analyse each of the 16 factors in the description of the state of the industry and to weigh them in the assessment. ${ }^{65}$

MOFOM's failure to provide adequate reasoning for its findings therefore led the Panel to conclude 'that MOFCOM did not conduct an objective examination of the evidence'. ${ }^{66}$

\section{F. Causality}

In its causality analysis, MOFCOM found that price undercutting existed in the first two years of the investigation period, but not in the final year, and that the imported product's prices were suppressing those of the domestic industry. It also found that the exporter was gaining market share at the expense of the industry and that imports were increasing rapidly. MOFCOM found that 'Nuctech was forced to maintain its prices at a low level in order to be able to compete with Smiths [the exporter]. If not, it would have lost even more sales to Smiths' ${ }^{67}$ MOFCOM relied both on the 'great volumes' and the 'low' prices of the subject imports to find that 'the EU exported X-ray security inspection equipment to China in large volumes and at lower prices, causing serious effects on the production and operations of domestic security inspection equipment' ${ }^{68}$ MOFCOM concluded that the dumped imports were the only cause of the industry's injury in 2008.

The Panel noted that article 3(5) of the AD Agreement requires an investigating authority to demonstrate 'that the dumped imports are, through the effects of dumping ... causing injury' to the domestic industry. In analysing MOFCOM's findings it held, with reference to the Appellate Body in US-Softwood Lumber $V I,{ }^{69}$ that MOFCOM's explanation of the causal mechanism by which the dumped imports caused injury to the domestic industry 'was not reasoned and adequate'. ${ }^{70}$ It noted that the EU and China disagreed as to whether there was a correlation between the prices of the subject products and those of the domestic like product. ${ }^{71}$

64 Ibid., para. 7(204).

65 Ibid., para. 7(215).

66 Ibid., para. 7(216).

67 Ibid., para. 7(245).

68 Ibid., V 7(251).

69 US-Softwood Lumber VI (Article 21.5-Canada) Appellate Body Report, para. 93.

70 China-X-ray Equipment Panel Report, para. 7(244).

71 Ibid., para. 7(246). 
Although the Panel acknowledged that an overall correlation between dumped imports and injury to the domestic industry may support a finding of causation, it held that:

\begin{abstract}
such a coincidence analysis is not dispositive of the causation question; causation and correlation are two distinct concepts. In the circumstances of this case, even accepting China's position that the domestic industry experienced injury as the dumped imports entered the market at large volumes and low (albeit increasing) prices, in the Panel's view, the causation question is not resolved by such a general finding of coincidence. ${ }^{72}$
\end{abstract}

The Panel found that MOFCOM had failed to indicate in its final determination how the prices and volumes of the subject product interacted with those of the industry and, as a result, that there was nothing in the final report that could assist the Panel to conclude that MOFCOM's findings on price and injury alone could sustain a finding of causal link between the dumping and the injury. ${ }^{73}$ When China indicated, in response to a question by the Panel, that imports were increasing rapidly and that the exporter was increasing its market share, the Panel "noted that MOFCOM did not provide this explanation in its Final Determination' ${ }^{74}$ and that, in fact, the domestic industry was increasing its market share. Consequently, the Panel found that:

MOFCOM did not provide a reasoned and adequate explanation regarding how the dumped imports caused price suppression in the domestic industry, particularly in 2008 when the prices of the dumped imports were above those of the domestic industry. For this reason, the Panel is of the view that the MOFCOM did not conduct an objective examination of the evidence... ${ }^{75}$

Accordingly, an investigating authority not only has to evaluate and correlate injury information but also has to specifically determine whether such correlation is indicative of a causal link; has to properly consider any other factors contributing to the industry's injury; and has to properly set out its reasoning in its final report.

With all these pointers provided in China-X-ray Equipment, the following section analyses ITAC's actual procedures to determine to which extent ITAC's procedures meet the stringent test set by the Panel.

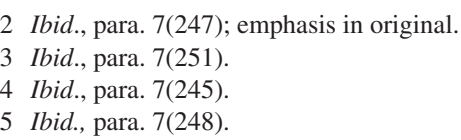




\section{EVALUATING SOUTH AFRICA'S INJURY AND CAUSALITY INVESTIGATION PROCEDURES}

\section{A. Introduction}

The analysis below evaluates ITAC's injury and causality determinations and measures these to the WTO requirements, as interpreted in China$X$-ray Equipment. The analysis specifically considers the injury and causality determinations in four recently completed investigations: Poultry (Brazil), ${ }^{76}$ Frit (Brazil), ${ }^{77}$ Threaded rod (China) ${ }^{78}$ and Set screws (China).${ }^{79}$ The analysis focuses only on the factors raised in China-X-ray Equipment and does not take into consideration other factors, unless this is important in the causality analysis, or where this directly impacts the rest of the analysis.

\section{B. Price injury determinations in South Africa}

Although article 3(2) of the AD Agreement only requires an authority to consider the price effects of dumping and then indicates that this can be done with reference to price undercutting, depression 'or' suppression, ITAC always investigates all three price factors. It can therefore be argued that, in this regard, South Africa's procedures more than meet the WTO requirements. This does not mean that the actual analyses conform to the requirements, as will be evident from the evaluation below.

In Poultry (Brazil), ITAC split the investigation into two product groups: whole birds and boneless portions. This is akin to the requirement in China-X-ray Equipment that low-energy and high-energy scanners constituted two product categories. In conducting its price undercutting exercise, ITAC found that:

The SACU industry's ex-factory prices are compared with the landed cost of the imported product to determine price undercutting. ... The landed cost was based on the CIF export price plus the applicable customs duty and clearing and wharfage costs. The Commission made a final determination that the alleged dumped imports undercut the Applicant's selling prices. ${ }^{80}$

There are several types of whole birds. The applicant in determining the normal value for whole birds submitted prices relating to three distinctly different types of whole birds, which had very different prices. Both the importers and the exporters had submitted evidence that both whole birds and carcasses, that is, products with all cuts stripped, were imported under the same tariff heading and that carcasses attracted significantly lower prices than whole birds. ITAC disregarded these comments and never undertook any analysis in this regard. Accordingly, it

76 See Poultry (Brazil)(ITAC Report 399).

77 See Frit (Brazil)(ITAC Report 414).

78 See Threaded rod (China)(ITAC Report 420).

79 See Set Screws (China)(ITAC Report 408).

80 Poultry (Brazil)(ITAC Report 399) para. 5.2.2.1. 
was comparing the price of the imported products, which included different types of whole birds and carcasses, with domestic whole bird prices. It follows that no price comparability analysis was undertaken. No attempt had been made to determine whether the landed cost was the correct level to compare prices with those of the domestic industry. Further, as in China-X-ray Equipment, ITAC's questionnaire does not require the domestic industry to supply sales information on a transaction-by-transaction or product-by-product basis. Accordingly, in view of the panel's decision, ITAC was not in a position to determine price undercutting for whole birds. ${ }^{81}$ As regards boneless cuts, ITAC found as follows in respect of price undercutting:

The landed cost was based on CIF export price plus the applicable duty and clearing and wharfage cost.

[The importer's] information was verified and used to determine the landed cost. Based on this the Commission determined that the applicant experienced significant price undercutting of $36.67 \% \ldots{ }^{82}$

This represents the complete analysis ITAC undertook and fails to address the fact that there are several different boneless cuts, such as breasts, skinless breasts, thighs, drumsticks and leg quarters. All of these products command different prices. In Brazil's request for formal consultations under the Dispute Settlement Body it indicated that ITAC had determined the average price for boneless cuts on the basis of only a single product. ${ }^{83}$ In addition, the domestic industry was not required to provide pricing information on a product-by-product basis. ITAC found that the industry was experiencing price suppression, as its cost-to-price ratio increased from 100 to 102 over the period, after reaching a level of 105 in the middle period, but did not address the question whether this was 'significant', as required by article 3(2) of the AD Agreement. Interested parties made several submissions in this regard, which led to ITAC's final determination that:

The price suppression level of 2010 shows an improvement from 2009 which was higher than 2008 and 2010. The applicant's information shows indicates that price suppression experienced increased during the period of investigation... ${ }^{84}$

The Commission considered that although price suppression determination may be about whether it existed, the question of whether it increased or decreased is relevant as the existence or not of price suppression is assessed during the period of investigation and therefore existence has to be linked to the dumped imports. ${ }^{85}$ [sic]

81 Ibid., para. 5.2.2.3

82 Ibid., para. 8.2.1.

83 WTO, South Africa-Anti-Dumping Duties on Frozen Meat of Fowls from Brazil WT/DS439/1 (25 June 2012).

84 The omitted information briefly listed, in a four-line paragraph, interested parties' comments.

85 Poultry (Brazil)(ITAC Report 399), para. 8.2.3. 
This constituted ITAC's complete determination of price undercutting, without making any reference to the differences that existed between the different products or whether the price undercutting was significant.

In Set screws (China) the subject product is described as:

Fully threaded screws with hexagon nuts (including cap screws) of iron or steel, with or without threads ... of a thread diameter of $6 \mathrm{~mm}$ or more, but not exceeding $36 \mathrm{~mm} \ldots$ and a length of $10 \mathrm{~mm}$ or more but not exceeding $400 \mathrm{~mm}$, whether or not with their nuts and washers. $^{86}$

The product was classifiable under tariff subheading 7318.15.90 until December 2010 and thereafter under 7318.15.39. The investigation period ran from July 2008 to June 2011. This distinction is extremely important, as threaded rod was also classifiable under tariff subheading 7318.15.90 until December 2010, whence it became separately classifiable. The investigation period in threaded rod was from January 2008 to December 2010, indicating significant overlap between the two investigation periods for different products classifiable under the same tariff heading.

The price undercutting analysis in Set screws (China) was as follows:

... Price undercutting of $55.37 \%$ was determined.

The price undercutting is based on FOB information of the two exporters that were found to be dumping, plus sea freight, marine insurance, warfage [sic], cartage obtained from the verified importers and import duties to arrive at a landed cost.

The Applicant stated that the subject product is imported from PRC at abnormally low prices on a continuous basis, forcing the SACU producers to sell the subject product (sic) at prices which are at unprofitable levels or face a significant reduction in sales volumes resulting in increasing inventories. ${ }^{87}$

It should be noted that ITAC determined the margin of dumping separately for different product types. ${ }^{88}$ No such distinction was drawn in determining price undercutting and the question is why ITAC found it important enough to distinguish between these product groups when determining dumping, that is, the cost and price differences were sufficient to warrant separate treatment, yet it did not find this important in making the price comparison with the domestic like product. ITAC found both price depression, on the basis that average prices decreased by 18 per cent during the investigation period, and price suppression, on the basis that the cost of production only decreased by 3 per cent. ITAC did not distinguish between different product categories in either case, nor did it reflect comments by the exporters and importers that stated that ITAC could not rely on

88 Ibid., para. 4.6.1. 
the same information to find injury in respect of both set screws and threaded rod. ITAC made no attempt at distinguishing between these products.

In Threaded Rod (China) the full price undercutting analysis reflected in ITAC's final report read as follows:

The Applicant stated that threaded rods are imported from the PRC at abnormally low prices on a continuous basis, forcing the SACU producers to sell threaded rods at prices which are at unprofitable levels or face a significant reduction in sales volumes resulting in increasing inventories. ${ }^{89}$

Threaded rods come in two standard lengths, being $1 \mathrm{~m}$ and $3 \mathrm{~m}$, as well as in various diameters and made of different materials. ITAC made no effort to differentiate between the different products, nor did it provide any reasoning why it could rely on the weighted average price for all models. No reference is made to any actual findings, as the report merely indicates that the applicant 'alleged' price undercutting. In its price depression determination, ITAC listed the weighted average price for each of three product categories, being 'mild steel/galvanised/black', 'stainless steel' and 'EN8', as well as the weighted average price for all products. Thus, no differentiation was made for price differences between galvanised and ungalvanised products or for size differences. ITAC finds price depression as the table above indicates that price depression occurred'.$^{90}$ As regards price suppression, ITAC separately analyses each of the three product categories identified under price depression. Although for stainless steel products the information in the table shows that prices decreased from 100 to 70 over the period while costs decreased from 100 to 69 , that is, there is no price suppression, ITAC makes a single finding in respect of all products, indicating that the information 'indicates that prices did not increase by at least the same margin as the cost and therefore, the SACU industry experienced price suppression'. ${ }^{91}$

The price undercutting exercise in Frit (Brazil) is significantly more detailed and provides:

The landed cost was calculated and it was found to be undercutting the Applicant's selling price by 56.81 per cent.

The applicant indicated that the undercutting of prices by the dumped Brazilian product has had a significant effect on the local industry, resulting in prices being driven down and jobs which should have been created not materialising.

The applicant further stated that it is unable to drop their prices any further and should the price undercutting continue, it would have to consider other options to remain competitive and these options would include a further reduction in staff or the closure of the manufacturing facility.

89 Threaded Rod (China)(ITAC Report 420), para. 5.2.2.

90 Ibid., para. 5.2.2.

91 Ibid., para. 5.2.2 


\section{Summarised comments from interested parties (Smalticeram Do Brasil Ltda.)}

The exporter stated that when it calculated the price undercutting, it found that the undercutting percentages range from 13 to 18 per cent. It also stated that [the domestic industry's] selling price should not have been compared with the landed price of the frit as the level of trade was different.

\section{Commission's consideration}

The Commission considered that the undercutting percentage calculated by the exporter was not substantiated and thus not relevant.

The level of trade between the landed cost and the applicant does not apply to the calculation of price undercutting. ${ }^{92}$

On the one hand, this analysis shows that ITAC considered interested parties' comments and made decisions on that basis, even though its finding that the level of trade does not play a role in the price undercutting determination is incorrect, as shown by the panel and as the ADR specifically define price undercutting as 'the extent to which the price of the imported product is lower than the price of the like product produced by the SACU industry, as measured at the appropriate point of comparison' ${ }^{93}$

Considering the panel's finding in China-X-ray Equipment, where it stated that where different products were under investigation, price undercutting, depression and suppression could not simply be determined on the basis of a basket of products, but that cognisance had to be given to differences in the product mix, or that prices had to be determined on a model-by-model or product group-by-product group basis, it is submitted that ITAC's procedure would not survive scrutiny by a panel.

\section{ITAC's evaluation of the $\mathbf{1 5}$ material injury factors}

Several Panels, ${ }^{94}$ including China-X-ray Equipment, ${ }^{95}$ have confirmed that a proper 'evaluation' of injury factors needs to be undertaken. As indicated above, in Poultry (Brazil) ITAC split the investigation into two product groups and separately analysed those injury factors that could be separately identified. The importance of splitting the injury analysis into the two product categories becomes clear when the factors are evaluated. The following analysis relates to whole birds. ITAC found that: ${ }^{96}$

- sales volumes increased by $3 \%$;

- sales values increased by $4 \%$;

92 Frit (Brazil)(ITAC Report 414), para. 5.2.2.1; author's emphasis added.

93 AD Regulation 1; author's emphasis.

94 See, e.g. US-Shirts and Blouses Panel Report, para. 7.25; Guatemala-Cement II Panel Report, para. 8.285; Mexico-HFCS 21.5 Panel Report, para. 6.34-6.35.

95 China-X-ray Equipment Panel Report, paras 7.178-7.183.

96 Poultry (Brazil)(ITAC Report 389), para. 5.3.1-5.3.16. 
- industry moved from a loss situation to being profitable;

- output increased by $4 \%$;

- productivity (for all products) increased by $3 \%$;

- return on investment (for all products) increased nine-fold;

- capacity utilization (for all products) remained stable over the investigation period despite capacity increasing by $6 \%$;

- net cash flow (all products) moved from negative to positive;

- inventory volume and value increased by $28 \%$ and $32 \%$, respectively;

- employment (all products) increased by $6 \%$;

- total wages (all products) increased by $11 \%$, while wages per worker increased by $5 \%$;

- capital invested in the product (all products) increased by $13 \%$, and annual capital expenditure also increased;

- industry experienced smaller growth (3\%) than the growth in the market (72\%); and

- industry's market share decreased by $40 \%$, while the dumped imports' market share increased by $117 \%$ and that of other imports by $65 \%$.

ITAC provided a table setting out each of these indices, that is, showing that sales volumes moved from 100 in year 1, to 137 in year 2 and 103 in year 3, and then the statement as captured above. No further analysis was undertaken to evaluate the effect of sales volumes decreasing from 137 to 103 in the final period. As regards the two remaining injury factors, ITAC found that the 'factor affecting domestic prices is price undercutting' and, as regards the dumping margin merely listed the margin found. No further analysis is undertaken of either these factors. On the basis of the injury indicators above, ITAC found that the domestic industry was suffering material injury in the form of price undercutting, market share and growth. ${ }^{97}$ It is therefore clear that ITAC 'merely recited' the information and had not properly evaluated the different factors. Note that the import statistics for whole birds included carcasses that did not form part of the investigation and that ITAC failed to conduct any investigation to exclude carcasses. It was shown throughout the investigation that ITAC had relied on inaccurate import statistics that had not been supplied by Customs, but by the applicant. ${ }^{98}$ Information from Customs showed that the total volume of imports from Brazil was significantly lower (in ITAC's figures import volumes in the final year were overstated by more than 25 per cent). These facts seriously undermine ITAC's findings in respect of price undercutting, market share and growth. Scrutiny of the public file also shows that importers and exporters had submitted information on injury that is

97 Ibid., para. 5.4

98 See, e.g. WTO, South Africa-Anti-Dumping Duties on Frozen Meat of Fowls from Brazil WT/DS439/1 (25 June 2012) 2. 
not referred to in the report at all. It appears, therefore, that ITAC's analysis as regards whole birds would not have withstood scrutiny by a Panel. ${ }^{99}$

As regards boneless cuts, ITAC found that: ${ }^{100}$

- sales volumes decreased by 2 per cent (the index shows that sales volumes moved from 100 to 107 to 98 ) - one would have expected ITAC to evaluate the decrease in the final year;

- sales values increased by 5 per cent (index shows 100-115-05)one would have expected ITAC to evaluate the decrease in the final year;

- profit decreased (from 100-49-92) - here one would have expected ITAC to interrogate the significant improvement in profitability in the final year, especially in light of decreasing sales;

- output decreased (100-09-94);

- productivity increased (by 3\%);

- return on investment (all products) increased nine-fold;

- capacity utilisation (for all products) decreased (100-111-88) - but no reference is made to the fact that capacity had increased during the period;

- net cash flow (all products) moved from negative to positive;

- inventory volume and value decreased;

- employment (all products) increased;

- total wages (all products) increased;

- capital invested (all products) increased by 13 per cent, and annual capital expenditure also increased;

- industry experienced smaller growth ( -2 per cent) than the growth in the market ( 32 per cent); and

- industry's market share decreased by 27 per cent while the dumped imports' market share increased by 17 per cent and that of other imports by 300 per cent.

For each of these factors, ITAC provided a table setting out the indices only and then the statement as captured above. No further analysis was undertaken. For instance, as regards whole birds inventories it is simply stated that industry's inventories 'increased during the period of investigation', whereas for boneless cuts it is stated that the 'inventory levels for boneless cuts decreased', without indicating whether the increase or decrease would be indicative of injury or why.

As regards factors affecting domestic prices, ITAC made verbatim the same finding as for whole birds: the 'factor affecting domestic prices is price undercutting'. For margin of dumping it included a table stating the dumping margin for the cooperating exporter and the residual dumping margin. Considering that seven of the fifteen factors were positive, that one (other factors affecting prices) was not addressed at all, while seven factors were negative, it is submitted

99 Note that Brazil challenged inter alia ITAC's injury determination before the WTO.

100 Poultry (Brazil)(ITAC Report 389), para. 5.3.1-5.3.16. 
that a simple conclusion that the industry suffered injury in the form of the seven negative factors is insufficient to meet the threshold the panel set in X-ray Equipment.

ITAC's injury determination in Set Screws stands in stark contrast to that in Poultry (Brazil) and contains a brief analysis of the different injury factors. Thus, as regards sales volumes, ITAC provides an index setting out the trend in sales and then indicates that:

Table 5.2.3.1 [sic] shows a decrease in sales volume during the investigation period. The applicant indicated that the decrease in sales volume is evident owing to the increase in imports. The Commission noted that imports decreased during the period of investigation, in particular the dumped imports from the PRC. However, it also noted that although the dumped imports are showing a declining trend, they still occupy a large part of the SACU market. ${ }^{101}$

As part of its analysis, ITAC indicates that it "noted that the applicant had to decrease its selling prices in an effort to maintain presence in the market and compete with the imported products' ${ }^{\prime 102}$ while it found that the industry's decrease in profits 'can be linked to the decrease in sales values, decrease in selling prices, high cost of production and a decrease in sales volumes' ${ }^{103}$ and that 'output declined in line with a decreasing market and also as a result of the dumped imports that still occupy a large part of the SACU market'. ${ }^{104}$ Similar analyses are provided as regards market share, productivity, capacity utilisation, cash flow, growth and investments. On the margin of dumping, ITAC listed the margins of dumping in respect of each of the cooperating exporters, which varied from zero to 21.5 per cent for cooperating exporters and 76.3 per cent for non-cooperating exporters, and then added that 'the magnitude of dumping for those found to be dumping, including the non-cooperating [exporters] is significant'. ${ }^{105}$ It further noted that the applicants are members of an industrial organisation and party to wage agreements reached in the industry as a whole. This means that there was some analysis of eleven factors.

Despite indicating in respect of profit that the industry had high production costs, that the price suppression analysis shows significantly increasing costs and that non-dumped imports are significantly cheaper, ITAC indicated that the 'applicant stated that there are no other known factors that could affect domestic prices negatively'. ${ }^{106}$ This shows that ITAC relied exclusively on the applicant's statement and did not evaluate the factor. As regards inventories, ITAC simply indicated that inventories had grown despite reduced production, while it noted that the employment related to all products and not only the like product.

101 Set screws (China)(ITAC Report 408), para. 5.3.1.

102 Ibid., para. 5.3.2.

103 Ibid., para. 5.3.3

104 Ibid., para. 5.3.4

105 Ibid., para. 5.3.10.

106 Ibid., para. 5.3.9; author's emphasis. 
Although this shows a much improved injury analysis, ITAC's failure to properly evaluate price undercutting, return on investment, factors affecting domestic prices and employment means that it still did not fully meet the Panel's requirements.

In Frit (Brazil), ITAC referred to the applicant's assertions ('the applicant stated ...') as regards sales volumes, output, market share (partially), productivity, return on investment, capacity utilisation, inventories (where ITAC noted that it could not properly verify inventory levels) and wages, without undertaking any further analysis. ITAC found that sales volumes, sales values, profit, output, productivity, capacity utilisation and wages all increased, while employment remained stable. In the index on profit, ITAC indicates that gross profit had increased by 26 per cent, but in its return on investment index, it shows that net profit had decreased by 25 per cent. No further analysis is undertaken or explanation given for the divergent gross and net profit results. Bearing in mind that the volume of sales also increased, it indicates that overheads were not divided by fewer sales to cause the change in net profit. No analysis was undertaken in respect of factors affecting prices, while the dumping margins were stated without any further analysis or even indicating whether the margins were deemed significant.

ITAC found that employment remained stable despite the information showing that employment had first decreased by 29 per cent and then decreased to the original figure in the final year. ITAC noted that it 'analyses each injury factor over the period of investigation. While employment increased in 2009/10, the employment figure during the investigation period remained stable' ${ }^{107}$ This interpretation cannot be supported, as the injury was clearer in the final year, as also supported by imports, which increased from 490 tonnes in the first year to 650 tonnes in year two and 1,047 tonnes in the final year. Considering the trend in imports, one would have expected significantly greater attention being given to the injury trends in the final year.

Nonetheless, on the basis that the domestic industry had lost market share, ${ }^{108}$ experienced decreased cash flow, growth and ability to attract investments, and as it experienced price depression and undercutting, ${ }^{109}$ ITAC found that the industry had experienced injury. No analysis was done to determine the interaction between positive and negative factors. Accordingly, ITAC's injury evaluation in the Frit (Brazil) investigation would also not have survived a panel's scrutiny.

In Threaded Rod (China) ITAC determined price depression and suppression separately for three different product categories, being 'mild steel/galvanized/ black', stainless steel and EN8. In the rest of its injury determination, ITAC then merges the first and third categories into a single category for some factors (sales, output and inventories) and merges everything into a single category for other factors without providing any basis for the mergers. As regards 12 of

107 Frit (Brazil)(ITAC Report 414), para. 5.2.3.13.

108 Note that although ITAC had found the industry had lost market share, this is not indicated as a factor playing a role in ITAC's injury determination - see para. 5.3.

109 In para. 5.2.2.3 ITAC also found price suppression, but did not list this as a factor supporting its injury determination. 
the 15 factors ITAC merely indicates what the applicant had stated, no analysis was done in respect of factors affecting domestic prices, ${ }^{110}$ a negative margin of dumping was found (that is, no dumping), while the profit evaluation simply provides an index at gross and net level separately for the two product categories, and then indicates that the information 'indicates that the Applicant's profit declined for both categories...'.111

As regards sales volumes, ITAC indicates that the applicant stated that its sales remained 'more or less static' over the period, except in respect of stainless steel products, where sales decreased. Scrutiny of the information in the index, however, shows that sales decreased in respect of both stainless steel and other rods in the first period and then increased again in the second period, from 69 to 75 for stainless steel and from 92 to 102 for other rods, but no analysis of these trends was undertaken, despite the fact that imports showed a similar trend, that is, decreasing in the first period and increasing in the second period. ${ }^{112}$ In its overall finding on injury ITAC states it:

took into account that an industry normally suffers either 'price' or 'volume' injury. From the information above, the Commission found that it was not evident that the Applicant is suffering volume injury, given the sales and output figures. The Commission, however, found clear evidence that the Applicant was suffering price injury, considering the decline in prices, profits and cash flow. The Commission therefore made a final determination that the Applicant. .. was suffering material injury. ${ }^{113}$

Although this conclusion shows deeper evaluation than in respect of any of the individual factors, by virtue of the fact that ITAC did not conduct an evaluation of each of the fifteen factors, its injury analysis in this case does not meet the standard set in $X$-ray Equipment. It is submitted that ITAC has not 'evaluated' the injury factors and would fail scrutiny by a panel.

\section{A. Interaction between injury factors}

In the analysis of the Panel's evaluation of MOFCOM's injury determination it was indicated that one of MOFCOM's shortcomings was that it had not properly analysed the relationship between the different injury factors and, specifically, between factors showing positive and negative trends. To recap, the panel held as follows:

aside from listing all 16 injury factors and the trends observed in them over the course of the POI, MOFCOM did not otherwise refer to

110 This appears to be a shortcoming in all investigations, as ITAC often indicates that the applicant indicated that domestic prices were affected by the imports, but fails to investigate any other factors affecting domestic prices.

111 Threaded rod (China)(ITAC Report 420), para. 5.2.3.2.

112 Note that ITAC indicated the trend for the 'alleged dumped import' despite finding no dumping.

113 Threaded rod (China)(ITAC Report 420), para. 5.4. 
or explain the developments in capacity utilization, productivity and wages in the descriptive section of its analysis of the industry. In the Panel's view, a more balanced approach would have been explicitly to analyse each of the 16 factors in the description of the state of the industry and to weigh them in the assessment. ${ }^{114}$

In particular, we consider that such a situation would require a thorough and persuasive explanation as to whether and how such positive movements were outweighed by any other factors and indices which might be moving in a negative direction during the $[\mathrm{POI}]{ }^{115}$

It has already been shown above that ITAC did not make a holistic determination by considering the interaction between the trends for the different injury factors, or the relationship between positive and negative factors. This is most evident from its analysis of the whole birds in the Poultry (Brazil) investigation. Considering that ITAC does not consider the relationship between the different injury factors, a panel would find its injury assessment to be in violation of its WTO obligations.

\section{B. Causality determinations in South Africa ${ }^{116}$}

ITAC's causality analysis consists of two parts: first, a part setting out the positive links between the dumping and the injury and, second, other factors that contributed to the injury. This is then followed by an overall conclusion.

In Poultry (Brazil), ITAC, as regards dumping as cause of injury, listed the market share of the industry, the dumped imports and other imports, separately for the two product groups. It failed to recognise that the import statistics were incorrect and overstated by at least 25 per cent. It also failed to exclude carcasses from the volume of whole bird imports, despite these issues being raised by the importers on several occasions. ${ }^{117}$ ITAC indicated that there was price undercutting (but no suppression or depression) as regards whole birds (which included the price for carcasses) and that there were both price undercutting and suppression as regards boneless cuts. It provided a table with two columns for whole birds and boneless cuts, restating its injury finding, but simply indicating whether the information for each factor showed an increase or a decrease, without undertaking any analysis. This constitutes its complete finding on dumping as cause of injury.

114 China-X-ray Equipment Panel Report, para. 7.215; author's emphasis.

115 Thailand-H-Beams Panel Report, para. 7.249; author's emphasis. See also EC-Countervailing Measures on DRAM Chips Panel Report, para. 7.372 and EC-Fasteners Panel Report, para. 7.399 .

116 Note that no causality analysis was carried out in Threaded rod (China) as ITAC did not find dumping.

117 Neither of ITAC's two essential facts letters made any reference to these issues and ITAC's final recommendation to impose anti-dumping duties, which the Minister rejected, still did not deal with these issues. 
Table 1. Import volumes: whole chickens

\begin{tabular}{llll}
\hline & $\mathbf{2 0 0 8}$ & $\mathbf{2 0 0 9}$ & $\mathbf{2 0 1 0}$ \\
\hline Alleged dumped imports (kg) & 3280599 & 12914776 & 12954549 \\
Other imports (kg) & 5748265 & 13719494 & 16084772 \\
Total imports (kg) & 9028864 & 26634270 & 29039320 \\
Alleged dumped imports (\%) & 36.33 & 48.48 & 44.6 \\
as a\% of total imports & & & \\
\hline
\end{tabular}

ITAC then moves to factors other than the dumping that could be contributing to the injury. For all practical purposes, it deals only with the volume of other imports, as it found that:

- the industry's technology is 'comparable with global technology', indicating that no comparison is done with Brazilian technology, and no basis is provided for its finding;

- the applicant 'is not traditionally export-oriented'; and

- no information was provided on competition between the imports and the domestic product other than price, despite several submissions to the contrary. ${ }^{118}$

These findings require further scrutiny and this can only be done with reference to the submissions contained on the public file, as none of the issues is reflected in ITAC's report or the essential facts letters. Starting out with ITAC's analysis of import volumes from other countries, ITAC provides the following information in tabular format (Table 1).

Table 1 indicates that the imports of whole birds from Brazil increased from 36.33 per cent in 2008 to 44.6 per cent in 2010 .

However, what is clear from the above is that imports from Brazil remained stable in 2010 (an increase of 0.3 per cent), whereas imports from other countries increased by 17.2 per cent to a volume 24 per cent higher than the volume from Brazil. Not reflected here, is the trend in the domestic industry's sales, which were indexed as 100 in 2008, 137 in 2009 and 103 in 2010. Thus, domestic sales increased along with increased imports from Brazil and then decreased while imports from Brazil remained stable, while nothing is said about the fact that the import statistics still include carcasses. Import information shows that virtually all other products were imported from Argentina, that is, more whole birds were imported from Argentina than from Brazil, and prices from Argentina were 44 per cent lower than from Brazil. Thus, if the domestic industry experienced price undercutting vis-à-vis Brazil, price undercutting vis-à-vis Argentina must have been significantly higher. Although these arguments were raised on several occasions, they were not addressed. On this basis alone a panel would strike down

118 Information on product differences, including excessive brining by the domestic industry, the size of breast portions and the inclusion of carcasses in 'whole bird' statistics, is available on the public file. 
ITAC's findings on whole birds. The public file arguments also clearly show that ITAC relied on incorrect statistics in respect of boneless cuts and that the trends indicated in ITAC's findings are incorrect.

ITAC indicates that no information was provided on competition between the domestic and imported products. However, scrutiny of the public file indicates the contrary and that several other factors were submitted to ITAC. First, importers in the fast food industry indicated that industry's product could not be used for their hamburgers or pies as (a) the industry's deboned breasts were too small; and (b) the industry injected its product with a brine solution that altered the taste. This means that importers had no option but to import their requirements. In addition, it was indicated that the industry:

- injected its product with a brine solution up to 40 per cent of the total weight of the products, against national health legislation which only permitted a much lower figure;

- passed its products off as 'A-grade' product when it did not meet the legal specifications in this regard;

- after expiry of the sell-by date of the products, withdrew the product from the retailers, thawed it, washed it, refroze it and sold it again; and

- supplied customers with products that did not weigh as much as indicated on the packaging. ${ }^{119}$

All of these issues affected customers' perception of the domestic industry and affected its sales. Proof was also submitted that the single largest producer had taken a management decision to move away from the bottom end of the market (whole birds and cuts) to more processed products such as ready-made meals, which affected its volume of sales of the like product. ITAC disregarded all these issues. It is submitted that a panel would have found that ITAC did not conduct a fair and objective examination and was in violation of its obligations regarding the determination of causality.

In Set Screws (China) ITAC found that the dumped imports had decreased by 47 per cent over the period, including by 33.5 per cent in the final year, while other imports had increased by 25 per cent over the period, including by 48.2 per cent in the final year. The domestic industry's indexed sales had decreased from 100 to 90.13 , but then increased to 94.08 . Despite these trends ITAC found that the 'dumped imports from the PRC still occupy a large part of the SACU market' and that there was significant price undercutting, hence it found a causal link between the dumping and the injury. Although the injury analysis consisted of several product groups, no analysis was undertaken to determine price undercutting on a model or product group basis and no such information was requested from the industry. It therefore had no basis to make this comparison. In view of ITAC's failure to properly compare the prices of the subject and domestic like products

119 See the public file as regards all these issues. 
and its failure to explain how dumped imports that decreased by 47 per cent could contribute to the industry losing per cent sales volumes while other imports increased by 48 per cent, to a volume 25 per cent higher than that of the dumped imports, could cause the injury, it is difficult to see on what basis a panel would uphold ITAC's causality finding.

In Frit (Brazil), ITAC found that the dumped imports had increased from 490 tonnes to 1,047 tonnes, constituted 36 per cent of the SACU market, and undercut domestic prices by 56.81 per cent. It is not clear how the dumped product, at 1,047 tonnes, could constitute 36 per cent of the market, while other imports amounted to 1,837 tonnes ( 63 per cent). It therefore appears that ITAC meant to indicate that the dumped imports constituted 36 per cent of total imports, rather than of the market. However, despite other imports virtually doubling from 945 tonnes to 1,837 tonnes over the period, that is, a larger absolute increase in volume, and despite ITAC indicating that prices of other imports decreased from R11.65/kg to $\mathrm{R} 8.38 / \mathrm{kg}$ over the period, ITAC failed to indicate how the dumped imports could be regarded as causing injury when industry's sales volume increased by 33 per cent over the investigation period. There are thus many question marks over ITAC's causality analysis that remain unanswered and that would not survive scrutiny by a Panel. From the above it is submitted that ITAC's causality test does not meet the standard set by the Panel in X-ray Equipment.

\section{FINDINGS AND RECOMMENDATIONS}

The China-X-ray Equipment panel has set the standard for injury and causality analyses that all investigating authorities must attain. Analysis of the four most recent investigations in South Africa shows that ITAC is at serious risk of having all of its injury and causality findings struck down. This results from its failure to conduct 'a proper comparison' between the subject product and the domestic like product that takes into consideration differences between individual products and levels of trade; its failure to provide any analysis of injury factors by merely reciting the facts; its failure to reflect and evaluate the submissions made by interested parties; and its failure to properly explain on what basis it reached a finding of injury in cases where a large number of injury factors reflected positively, that is, did not show injury. Thus, any WTO member aggrieved with an ITAC finding would stand an excellent chance of having its decision declared in violation of its WTO obligations even if its exporters were dumping at substantial margins.

Accordingly, it is proposed that ITAC should:

- amend its injury questionnaire to require the industry to provide domestic sales information on a model-by-model basis;

- develop the methodology to compare the subject product price to the domestic like product price on a model-specific basis at an appropriate level of trade determined independently in each investigation; 
- conduct a proper analysis of each individual injury factor specifically indicating why the trends for such factor is indicative of injury or not;

- evaluate all comments by interested parties and reflect its evaluation in its published reports;

- develop a methodology for deciding material injury in cases where some factors are positive and others negative; and

- evaluate in more detail factors other than dumping contributing to material injury and isolate any injury caused thereby.

Once ITAC has incorporated these changes in its investigations, its analyses should withstand scrutiny by WTO panels. 